\title{
PRZEGLĄD ORZECZNICTWA SĄDÓW ADMINISTRACYJNYCH Z ZAKRESU GOSPODAROWANIA ODPADAMI
}

\section{UWAGI WPROWADZAJĄCE}

W ostatnich miesiącach sądy administracyjne wydały kilka orzeczeń, na które należy zwrócić szczególną uwagę. Są to orzeczenia dotyczące gospodarowania odpadami. Problemy poruszane $\mathrm{w}$ orzeczeniach dotyczą przede wszystkim zakazu prowadzenia działalności w zakresie zbierania: pozostałości z sortowania odpadów komunalnych, komunalnych osadów ściekowych, zakaźnych odpadów medycznych, zakaźnych odpadów weterynaryjnych, odpadów pochodzących z unieszkodliwiania zakaźnych odpadów medycznych lub zakaźnych odpadów weterynaryjnych innymi metodami niż termiczne przekształcanie.

* Doktor nauk prawnych, adiunkt w Katedrze Prawa Cywilnego Europejskiej Wyższej Szkoły Prawa i Administracji, Kancelaria Radców Prawnych s.c. dr K. Szuma, H. Zambrowicz-Rybarczyk w Poznaniu. 
Innym problemem, na który zwróciły uwagę sądy administracyjne jest ten dotyczący zbierania odpadów oraz poprawności skierowania zarządzenia pokontrolnego do podmiotu reprezentującego spółkę, a jednocześnie władnego podjąć decyzję o realizacji działań służących wyeliminowaniu naruszeń.

W końcu sądy administracyjne w ostatnich miesiącach rozstrzygały o miejscu przeznaczonym do zbierania (magazynowania) odpadów w kontekście stwierdzenia nieważności decyzji na zbieranie (magazynowanie) odpadów, jak również o okolicznościach wydania decyzji nakazującej posiadaczowi odpadów usunięcie odpadów z miejsc nieprzeznaczonych do ich składowania lub magazynowania.

\section{WYROK WSA W SZCZECINIE Z DNIA 29 MAJA 2012 R., SYGN. II SA/SZ 174/12}

$\mathrm{W}$ tej sprawie problem dotyczył stosowania art. 8 ustawy z dnia 22 stycznia 2010 r. o zmianie ustawy o odpadach oraz niektórych innych ustaw ${ }^{1}$, na podstawie którego posiadacz odpadów dotychczas prowadzący działalność w zakresie zbierania: pozostałości z sortowania odpadów komunalnych, komunalnych osadów ściekowych, zakaźnych odpadów medycznych, zakaźnych odpadów weterynaryjnych, odpadów pochodzących z unieszkodliwiania zakaźnych odpadów medycznych lub zakaźnych odpadów weterynaryjnych innymi metodami niż termiczne przekształcanie - może prowadzić swoją działalność w tym zakresie na podstawie zezwoleń, pozwoleń lub decyzji zatwierdzających program gospodarki odpadami niebezpiecznymi, nie dłużej jednak niż 3 miesiące od dnia wejścia w życie ustawy, o ile wcześniej nie straciły mocy. Natomiast zezwolenia, pozwolenia oraz decyzje zatwierdzające program gospodarki odpadami niebezpiecznymi, wygasają w całości lub w części dotyczącej zbierania po upływie 3 miesięcy od dnia wejścia w życie ustawy. 
W niniejszej sprawie ustalono, że decyzja Starosty udzielająca zezwolenia na prowadzenie działalności w zakresie zbierania odpadów innych niż niebezpieczne, zakresem swym obejmowała również pozostałości z sortowania odpadów komunalnych. Ustalenie to, przesądza, że zezwolenie na prowadzenie działalności w zakresie zbierania odpadów, w części, w jakiej dotyczy pozostałości z sortowania odpadów komunalnych, z mocy art. 8 ust. 1 pkt 2 ustawy z 2010 r. wygasło po upływie trzech miesięcy od dnia wejścia w życie tej ustawy. W związku z tym decyzja Starosty wygasła w części obejmującej zezwolenie na prowadzenie działalności w zakresie zbierania pozostałości z sortowania odpadów komunalnych. Wygaśnięcie części tej decyzji oznacza, iż nie istnieje ona w tym zakresie w obrocie prawnym, w rezultacie uprawniony pozbawiony został formalnych podstaw prowadzenia działalności polegającej na zbieraniu odpadów o konkretnym kodzie. W pozostałym zakresie decyzja udzielająca zezwolenia na zbieranie odpadów pozostała w mocy.

Wyeliminowanie z obrotu decyzji w części stanowiło trwałą przeszkodę w dokonaniu jej zmiany, na podstawie przepisu art. $155 \mathrm{kpa}$, decyzją Starosty, w odniesieniu do nieistniejącego już pkt 1 decyzji. Ta przeszkoda uzasadniała stwierdzenie, z urzędu, nieważności decyzji Starosty w części orzekającej o zezwoleniu na zbieranie odpadu, którego zbieranie zostało zabronione. W pozostałym zakresie nie stwierdzono nieważności decyzji. Treść art. 155 kpa, pozwala stwierdzić, że ma on zastosowanie jedynie do decyzji ostatecznych funkcjonujących w obrocie prawnym. Niedopuszczalna jest zatem zmiana decyzji nieistniejącej.

Organ rozpoznający sprawę wskazał nadto, iż oceniane $\mathrm{w}$ niniejszym postępowaniu zagadnienie prawne powstało przy rozpatrywaniu odwołania spółki od decyzji Burmistrza wydanej w trybie przepisu art. 34 ustawy z dnia 27 kwietnia 2001 r. o odpadach, nakładającej na tę spółkę obowiązek usunięcia odpadów, których zbieranie jest zabronione. Orzeczony nakaz był uzasadniony tym, iż spółka gromadziła bez zezwolenia odpady, co do których istnieje ustawowy zakaz zbierania. Wprawdzie organ wskazał, że spółka posiadała zezwolenie na zbieranie odpadów - 
pozostałości z sortowania odpadów komunalnych na podstawie decyzji Starosty, jednakże w związku z wejściem w życie art. 8 ustawy z dnia 22 stycznia 2010 r. o zmianie ustawy o odpadach oraz niektórych innych ustaw, decyzja Starosty utraciła moc.

Samorządowe Kolegium Odwoławcze po rozpoznaniu sprawy stwierdziło, że wykładnia art. 8 ust. 1 pkt 1 ustawy z dnia 22 stycznia 2010 r. o zmianie ustawy o odpadach nie uzasadnia wniosku o braku podstaw jego zastosowania do decyzji Starosty udzielającej zezwolenia na prowadzenie działalności w zakresie zbierania odpadów innych niż niebezpieczne. Przepis ten zezwolił posiadaczowi odpadów dotychczas prowadzącemu działalność w zakresie zbierania pozostałości z sortowania odpadów komunalnych na prowadzenie działalności w tym zakresie na podstawie zezwoleń, pozwoleń lub decyzji zatwierdzających program gospodarki odpadami niebezpiecznymi, nie dłużej jednak niż 3 miesiące od dnia wejścia w życie ustawy, o ile wcześniej nie straciły mocy. [...] Rozporządzenie Ministra Środowiska z dnia 27 kwietnia 2001 r. w sprawie katalogu odpadów określa katalog odpadów wraz z listą odpadów niebezpiecznych i sposób klasyfikowania odpadów. W myśl § 2 w katalogu określono odpady w zależności od źródła ich powstawania na 20 grup. Zgodnie z § 4 ust. 1 odpady klasyfikuje się według źródła powstawania w grupach 01 do 12 lub 17 do 20, przypisując im odpowiedni kod sześciocyfrowy określający rodzaj odpadu (wyłączając kody kończące się na 99), z zastrzeżeniem ust. 5 i 6 . W przypadku nieznalezienia odpowiedniej pozycji w grupach 01 do 12 lub 17 do 20, odpady klasyfikuje się w grupach 13, 14 i 15 (ust. 2). W przypadku nieodnalezienia odpowiedniej pozycji w grupach, o których mowa w ust. 2, odpady klasyfikuje się w grupie 16, zawierającej odpady nieujęte w innych grupach (ust. 3). W przypadku nieodnalezienia odpowiedniej pozycji w grupie 16, odpady klasyfikuje się w grupie według źródła powstawania, przypisując im kod kończący się na 99 (inne niewymienione odpady) - ust. 4.

Odpady ze specyficznych gałęzi przemysłu klasyfikuje się w kilku grupach, zwłaszcza odpady powstające przy produkcji samochodów klasyfikuje się w grupie 12 - odpady z kształtowa4/2012 nia oraz fizycznej i mechanicznej obróbki powierzchni metali 
i tworzyw sztucznych; 11 - odpady z chemicznej obróbki i powlekania powierzchni metali oraz innych materiałów i z procesów hydrometalurgii metali nieżelaznych; 08 - odpady z produkcji, przygotowania, obrotu i stosowania powłok ochronnych (farb, lakierów, emalii ceramicznych), kitu, klejów, szczeliw i farb drukarskich, w zależności od etapu produkcji (ust. 5).

Odpady opakowaniowe będące odpadami komunalnymi, jeśli są zbierane selektywnie lub występują jako zmieszane odpady opakowaniowe, klasyfikuje się w podgrupie 1501 , a nie w 2001 (ust. 6).

W rozpatrywanej sprawie w związku z treścią art. 8 ust. 1 pkt 1 ustawy zmieniającej, objęta postępowaniem zostaje grupa 19 - odpady z instalacji i urządzeń służących zagospodarowaniu odpadów, z oczyszczalni ścieków oraz z uzdatniania wody pitnej i wody do celów przemysłowych.

Przesłanką kwalifikacji „pozostałości z sortowania odpadów komunalnych" jest przyporządkowanie tych odpadów do odpowiedniej grupy. Z uwagi na źródło ich powstania, nie może budzić wątpliwości prawidłowość zakwalifikowania ich do grupy 19, jako pochodzących z instalacji i urządzeń służących zagospodarowaniu odpadów, a dalej do podgrupy 12, zawężającej i konkretyzującej źródło pochodzenia, tj. odpadów z mechanicznej obróbki odpadów (np. obróbki ręcznej, sortowania, zgniatania, granulowania), nie ujętych w innych grupach.

Stwierdzenie, nieważności decyzji w części zezwalającej na zbieranie odpadów obecnie zakazanych nie pozbawia stronę uprawnienia do zbierania odpadów stanowiących odpady mogące być poddanymi dalszemu zagospodarowaniu (odzyskowi), które zakwalifikowane zostały według innych kodów.

Oprócz powyższych pozostają też odpady, pochodzące z sortowania, nie ujęte we wskazanych podgrupach, a także $\mathrm{w}$ innych grupach, nie nadających się do dalszego odzysku, a w tym pozostałości z sortowania odpadów komunalnych, dla których jedynym zagospodarowaniem może być unieszkodliwienie.

Na powyższą decyzję skargę do Wojewódzkiego Sądu Administracyjnego złożyła Spółka A. zarzucając, że decyzja ta jest bezprzedmiotowa. 
Wojewódzki Sąd Administracyjny stwierdził, że sądowa kontrola zaskarżonej decyzji dokonana według kryterium zgodności z prawem dała podstawę do stwierdzenia, że skarga nie zasługuje na uwzględnienie.

Odnosząc się do treści zarzutów podniesionych w skardze, należy stwierdzić, że decyzją z dnia [...] r., znak [...] Starosta zezwolił Spółce A. na prowadzenie działalności w zakresie zbierania odpadów innych niż niebezpieczne, oznaczonych kodem [...] - lekka frakcja i pyły inne niż wymienione w [...] oraz kodem [...] - inne odpady (w tym zmieszane substancje i przedmioty) $\mathrm{z}$ mechanicznej obróbki odpadów inne niż wymienione $\mathrm{w}$ [...] . W treści decyzji organ określił obszar prowadzonej działalności, warunki jej prowadzenia, miejsce i sposób magazynowania odpadów, nałożył też na uprawnionego obowiązek w zakresie przekazywania odpadów, przestrzegania przepisów ochrony środowiska, prowadzenia ewidencji odpadów, przechowywania dokumentów, a także zapewnienia pracownikom zajmującym się transportem odpadów bezpiecznych warunków pracy.

Organ określił też datę ważności decyzji , a mianowicie do dnia [...]r. W związu z nowelizacją ustawy o odpadach z uwagi na treść art. 8 ustawy z dnia 22 stycznia 2010 r. o zmianie ustawy o odpadach oraz niektórych innych ustaw (Dz. U. Nr 28, poz. 145), który wszedt $w$ życie z dniem 12 marca 2010 r., posiadacze odpadów dotychczas prowadzący działalność w zakresie zbierania: pozostałości z sortowania odpadów komunalnych, komunalnych osadów ściekowych, zakaźnych odpadów medycznych, zakaźnych odpadów weterynaryjnych, odpadów pochodzacych z unieszkodliwiania zakaźnych odpadów medycznych lub zakaźnych odpadów weterynaryjnych innymi metodami niz termiczne przekształcanie - mogli prowadzić działalność $w$ tym zakresie na podstawie zezwoleń, pozwoleń lub decyzji zatwierdzających program gospodarki odpadami niebezpiecznymi, nie dłużej jednak niz 3 miesiące od dnia wejścia w życie ustawy, o ile wcześniej nie straciły mocy.

Decyzja Starosty z dnia [...] r. o udzielaniu zezwolenia na prowadzenie działalności w zakresie zbierania odpadów innych niż niebezpieczne, obejmowała zakresem swym również pozostałości z sortowania odpadów komunalnych, oznaczone kodem 4/2012 nr [...]. 
Klasyfikacja odpadów przyjęta w rozporządzeniu Ministra Środowiska z dnia 27 kwietnia 2001 r. w sprawie katalogu odpadów (Dz. U. z 2001r. Nr 112, poz. 1206), w załączniku - Katalog odpadów wraz z listą odpadów niebezpiecznych, w pozycji [...] ujmuje „Inne odpady” (w tym zmieszane substancje i przedmioty) z mechanicznej obróbki odpadów inne niż wymienione $\mathrm{w}[\ldots]$ przy czym w grupie oznaczonej numerem 19 mieszczą się odpady z instalacji i urządzeń służących zagospodarowaniu odpadów, z oczyszczalni ścieków oraz uzdatniania wody pitnej i wody do celów przemysłowych, podgrupie 1912 odpady z mechanicznej obróbki odpadów (np. obróbki ręcznej, sortowania, zgniatania, granulowania) nie ujęte w innych grupach. Trafnie stwierdził organ, że klasyfikacja ta stanowiła podstawę do uznania, iż odpad oznaczony kodem [...] obejmuje również pozostałości z sortowania odpadów komunalnych, jako pochodzące $\mathrm{z}$ instalacji i urządzeń służących zagospodarowaniu odpadów, dalej skonkretyzowane w podgrupie tych, które pochodzą z mechanicznej obróbki odpadów, w tym ich sortowania. Zasadny jest wniosek, że działalność obejmująca zbieranie odpadów o kodzie[...] , dotyczy wskazanych przez ustawodawcę w art. 8 ust. 1 pkt 1 ustawy o zmianie ustawy o odpadach, pozostałości z sortowania odpadów komunalnych.

Ustalenie to przesądza o tym, że zezwolenie na prowadzenie działalności $w$ zakresie zbierania odpadów, $w$ części, $w$ jakiej dotyczy pozostatości z sortowania odpadów komunalnych, z mocy art. 8 ust. 1 pkt 2 cyt. ustawy, wygasło po uptywie trzech miesięcy od dnia wejścia $w$ życie ustawy. W konsekwencji decyzja Starosty z dnia [...] r., znak [...] wygasła z dniem [...] r. w części obejmującej zezwolenie na prowadzenie działalności w zakresie zbierania odpadów oznaczonych kodem [...].

Wygaśnięcie części tej decyzji oznacza, usunięcie jej z obrotu prawnego, $w$ konsekwencji podmiot uprawniony na podstawie tej decyzji pozbawiony zostat prawnych podstaw prowadzenia działalności polegającej na zbieraniu odpadów o kodzie [...]. $W$ pozostatym zakresie decyzja udzielajaca zezwolenia na zbieranie odpadów pozostaje $w$ mocy $i$ stanowi podstawę do prowadzenia działalności $w$ zakresie wykraczającym poza wskazany odpad. 
Wyeliminowanie z obrotu decyzji $w$ części opisanej stanowito prawna przeszkodę $w$ dokonaniu jej zmiany, $w$ trybie art. 155 kpa, decyzją Starosty z dnia [...] r., znak: [...] , w odniesieniu do nieistniejącego już zapisu pkt. 1 decyzji, zezwalającego na zbieranie odpadu o kodzie [...] Ta okoliczność uzasadniała stwierdzenie, z urzędu, nieważności decyzji Starosty z dnia [...] r., znak: [...] w czesści orzekającej o zezwoleniu spótce A. na zbieranie odpadu o kodzie [...] , tj. w jej punkcie II, poz. 21 tabeli określającej kod i rodzaj odpadu. Pozostałej części decyzji nie dotyczy stwierdzenie nieważności i nadal jest ona podstawę prowadzenia określonej w niej działalności.

Nie jest zasadny zarzut strony skarżącej, że organ nie mógł orzec o częściowym stwierdzeniu nieważności decyzji. $W$ orzecznictwie sądów administracyjnych od dawana ugruntowany jest poglad, że brak $w$ Kodeksie postępowania administracyjnego przepisu wyraźnie dopuszczającego stwierdzenie nieważności decyzji tylko $w$ części dotkniętej wadq określonq $w$ art. 156 \& $1 \mathrm{kpa}$, nie oznacza wyłaczenia takiej możliwości. Tak więc stwierdzenie nieważności decyzji tylko $w$ części dotkniętej kwalifikowana wadliwościa jest nie tylko dopuszczalne, ale jako zgodne z zasadami ogólnymi Kodeksu postępowania administracyjnego, powinno być regułą działania właściwych organów (zob. wyrok NSA z dnia 21 stycznia 1988 r., IV SA 859/87).

Natomiast zasadny jest zarzut strony skarżącej, że organ odwoławczy nie powinien był określać jej rozważań zawartych w pismach procesowych, „dywagacjami”. Strona postępowania ma prawo wyrażać swoje stanowisko, nawet wtedy, gdy organ nie uznaje jego zasadności, i nie może być narażona na uwagi o charakterze emocjonalnym, od których organ winien się powstrzymać, formułując własny pogląd.

Uwaga ta nie zmienia jednak trafności stanowiska organu w kwestiach merytorycznych i nie może być podstawą uchylenia lub zmiany zaskarżonej decyzji". 


\section{WYROK WSA W BYDGOSZCZY Z DNIA 8 MAJA 2012 R., SYGN. II SA/BD 217/12}

W niniejszej sprawie organ zarzucił spółce prowadzenie bez wymaganego pozwolenia i zgody lokalizacyjnej działalności gospodarczej polegającej na zbieraniu odpadów złomu na terenie nieruchomości stanowiącej własność spółki.

Zarządzeniem pokontrolnym organ nakazał zaprzestać zbierania odpadów złomu bez wymaganego zezwolenia. Następnie spółka wezwała organ do usunięcia naruszenia prawa polegającego na błędnym określeniu adresata zarządzenia pokontrolnego. Ponadto spółka kwestionowała, jakoby na przedmiotowej nieruchomości zbierane były odpady. Organ uznał kwestionowane zarządzenie pokontrolne za prawidłowe.

Spółka wniosła do Wojewódzkiego Sądu Administracyjnego skargę na zarządzenie pokontrolne organu (Inspektora Ochrony Środowiska). Zaskarżonemu zarządzeniu skarżąca zarzuciła:

- naruszenie przepisów prawa materialnego, mające wpływ na wynik sprawy poprzez naruszenie art. 12 ust. 1 pkt. 1 ustawy z dnia 20 lipca 1991 r. o Inspekcji Ochrony Środowiska (tj. Dz. U. z 2007 r. Nr 44, poz. 287 z późn. zm., dalej: u.i.o.ś.),

- naruszenie przepisów prawa procesowego mogące mieć istotny wpływ na wynik sprawy, a w szczególności art. 7, art. $77 \S 1$ oraz art. 80 ustawy z dnia 14 czerwca 1960 Kodeks postępowania administracyjnego (tj. Dz. U. z 2000 r. Nr 98 Poz. 1071 z późn. zm., dalej: k.p.a.).

Zgodnie $\mathrm{z}$ art. 12 ust. 1 pkt 1 u.i.o.ś., jak podniosła skarżąca, zarządzenie pokontrolne może być skierowane do kierownika kontrolowanej jednostki organizacyjnej. Jak wskazuje się w doktrynie w przypadku, gdy kontrolowana jednostka ma złożoną strukturę, wówczas adresatem zarządzenia może być kierownik tej wyodrębnionej części jednostki, w której toku kontroli stwierdzono uchybienia (tak: T. Czech, Zarządzenie pokontrolne organów Inspekcji Ochrony Środowiska, Zeszyty Naukowe Sądownictwa Administracyjnego 2011, Nr 3, s. 89 
i n.). W przedmiotowej sprawie nie ulegało zdaniem skarżącej wątpliwości organu prowadzącego czynności kontrolne, że w przypadku działalności prowadzonej w B. przy ul. [...], kierownikiem oddziału jest A. K. To bowiem ona jest wymieniona jako „kierownik kontrolowanej jednostki” w protokole oględzin z dnia [...] października 2011 r. (s. 9). Została ona uznana za „kierownictwo kontrolowanej jednostki” (s. 9 protokołu), a więc to ją organ wskazał jako osobę, która winna podpisać protokół kontroli, który w świetle art. 11 ust. 2 u.i.o.ś. winien podpisać kierownik kontrolowanej jednostki organizacyjnej. Pomimo tego zarządzenie pokontrolne zostało skierowane do G. N. - prezesa zarządu [...] Sp. z o.o. Tym samym zarządzenie pokontrolne zostało wydane $\mathrm{z}$ rażącym naruszeniem prawa, jako że skierowano je do osoby, nie będącej, w świetle art. 12 ust. 1 pkt. 1 u.i.o.ś., kierownikiem kontrolowanej jednostki organizacyjnej. Podczas uprzednio prowadzonych na terenie zakładu czynności kontrolnych, których rezultatem był protokół kontroli [...], jako przedstawiciel podmiotu kontrolowanego występował A. M. - dyrektor zarządzający [...] Sp. z o.o. Tym samym organ, prowadząc czynności kontrolne, zaniechał wyjaśnienia, kto jest kierownikiem wyodrębnionej części jednostki, w której w toku kontroli stwierdzono uchybienia, a więc kto może być adresatem przedmiotowego zarządzenia pokontrolnego. Powoływanie się przez organ administracji publicznej na zapisy Krajowego Rejestru Sądowego uznać należy za niewystarczające. Ustawa o Inspekcji Ochrony Środowiska bowiem wprost przesądza, że adresatem zarządzenia pokontrolnego może być wyłącznie kierownik kontrolowanej jednostki organizacyjnej, nie posługując się pojęciem osoby reprezentującej dany podmiot, którym to pojęciem operują ustawy dotyczące prowadzenia działalności gospodarczej.

Prawidłowe określenie podmiotu, który jest adresatem zarządzenia pokontrolnego, jest o tyle istotne, że zgodnie $\mathrm{z}$ art. 31 u.i.o.ś. niewykonanie przez kierownika kontrolowanej jednostki organizacyjnej zaleceń podanych w zarządzeniu, może skutkować odpowiedzialnością karną.

Uzasadniając zarzut błędnego określenia przedmiotu dzia4/2012 łalności skarżąca podniosła, że podstawą nałożenia kwestiono- 
wanego zarządzenia pokontrolnego jest uznanie przez organ, iż na terenie nieruchomości prowadzona była działalność polegająca na skupie odpadów. Ustalenie powyższe oparte zostało na dwóch twierdzeniach: pierwszym, dotyczącym uznania, że głównym przedmiotem prowadzonej przez spółkę działalności gospodarczej jest skup odpadów oraz, drugim, wskazującym, że podczas przeprowadzonych w dniu [...] października $2011 \mathrm{r}$. oględzin przedmiotowej nieruchomości stwierdzono magazynowanie odpadów. Twierdzenia powyższe skarżąca uznała za wadliwe.

Skarżąca wywodziła, że nigdy nie prowadziła na terenie przedmiotowej nieruchomości działalności polegającej na skupie odpadów. Organ konsekwentnie ignorował składane zarówno podczas trwania kontroli, jak i po niej oświadczenia wskazujące, że na terenie nieruchomości położonej w B. znajduje się baza transportowa związana z prowadzoną przez spółkę działalnością polegającą na transporcie odpadów. Skarżąca zauważyła, że pomimo dwukrotnego przeprowadzenia czynności kontrolnych na terenie nieruchomości w 2011 r., nigdy nie stwierdzono, aby podczas jej trwania na działce prowadzona była działalność polegająca na skupie odpadów. Pomimo stosunkowo często podejmowanych czynności kontrolnych organy nigdy nie ustaliły, aby na terenie nieruchomości faktycznie dochodziło do czynności skupu odpadów. Z faktu zlokalizowania na terenie nieruchomości kontenera, w którym znajdują się niewykorzystywane przedmioty związane z prowadzoną działalnością gospodarczą, nie można wywodzić wniosku, jakoby prowadzony był skup złomu. Ponadto nieruchomość nie posiada jakiegokolwiek oznaczenia mówiącego o skupie.

Mając na względzie powyższe, skarżąca wniosła o uchylenie przedmiotowego zarządzenia pokontrolnego jako wydanego z rażącym naruszeniem prawa oraz o zasądzenie zwrotu kosztów postępowania według norm przepisanych.

[...] Inspektor Ochrony Środowiska w odpowiedzi na skargę nie zgodził się ze stawianymi przez skarżącą zarzutami i podtrzymał swoje dotychczasowe stanowisko. W uzasadnieniu organ wywodził m.in., że A. K. reprezentowała spółkę podczas kontroli prowadzonej w B. na podstawie udzielonego jej pełno- 
mocnictwa z dnia [...] listopada 2011 r. (zał. Nr 2 do protokołu kontroli), które upoważniało ją „Do reprezentowania Spółki w zakresie odbioru zawiadomienia o zamiarze wszczęcia kontroli, odbioru upoważnienia do przeprowadzenia kontroli, zakończenia kontroli, złożenia wyjaśnień i zastrzeżeń do protokołu kontroli oraz wszystkich czynności kontrolnych". Natomiast art. 12 ust. 1 pkt 1 u.i.o.ś. stanowi, że „na podstawie ustaleń kontroli [...] inspektor ochrony środowiska może: 1) wydać zarządzenie pokontrolne do kierownika kontrolowanej jednostki organizacyjnej lub osoby fizycznej”. Wydanie zarządzeń stanowi zatem czynność pokontrolną, o jakiej nie było zapisu w pełnomocnictwie.

$\mathrm{W}$ protokole $\mathrm{z}$ kontroli $\mathrm{w}$ rubryce Identyfikacja kontrolowanego zakładu, wymieniona jest firma [...] Sp. z o.o. [...], ul. [...], a adres kontrolowanej działalności to B., ul. [...]. Zgodnie z zapisem znajdującym się w Dziale 2 Rubryka 1 odpisu z rejestru przedsiębiorców Nr KRS: [...], uprawnionym do reprezentacji spółki jest prezes zarządu G. N., do którego zostały skierowane zarządzenia pokontrolne $\mathrm{z}$ dnia [...].11.2011 r., a który w przypadku braku oddzielnych uregulowań powinien być traktowany jak kierownik.

W kwestii magazynowania odpadów złomu organ stanął na stanowisku, że zastany stan faktyczny wypełnia definicję zbierania odpadów, zawartą w art. 3 ust. 3 pkt 23 ustawy o odpadach, która stanowi, że „Ilekroć w ustawie jest mowa o zbieraniu odpadów - rozumie się przez to każde działanie, w szczególności umieszczanie $\mathrm{w}$ pojemnikach, segregowanie i magazynowanie odpadów, które ma na celu przygotowanie ich do transportu do miejsc odzysku lub unieszkodliwienia".

Jak wynika z protokołu z oględzin (stanowiącego załącznik do protokołu kontroli $\mathrm{nr}$ [...] z dnia [...] października 2011 r.) oraz z załączonej dokumentacji fotograficznej przedstawiającej wypełnienie jednego z kontenerów odpadami złomu, odpady były umieszczone w pojemniku (kontenerze), magazynowane i przygotowane do ich transportu do miejsc odzysku.

Zgodnie z zapisem art. 28 cyt. ustawy, prowadzenie dzia4/2012 łalności w zakresie zbierania odpadów wymaga uzyskania ze- 
zwolenia, w tym przypadku starosty właściwego ze względu na miejsce zbierania odpadów.

Mając powyższe na uwadze, w opinii organu zaskarżone zarządzenie pokontrolne z dnia [...] listopada 2011 r. zostało wydane zgodnie $\mathrm{z}$ obowiązującą procedurą oraz stanem faktycznym.

Wojewódzki Sąd Administracyjny stwierdził, że „Zgodnie z art. $1 \S 1$ i 2 ustawy z dnia 25 lipca 2002 r. Prawo o ustroju sądów administracyjnych (Dz. U. Nr 153, poz. 1269 z późn. zm.), sądy administracyjne sprawują wymiar sprawiedliwości poprzez kontrolę działalności administracji publicznej, przy czym kontrola ta sprawowana jest pod względem zgodności z prawem, jeżeli ustawy nie stanowią inaczej. Sądy administracyjne, kierując się wspomnianym kryterium legalności, dokonują oceny zgodności treści zaskarżonego aktu oraz procesu jego wydania z normami prawnymi - odpowiednio: ustrojowymi, proceduralnymi i materialnymi - przy czym ocena ta jest dokonywana według stanu prawnego i na podstawie akt sprawy istniejących w dniu wydania zaskarżonego aktu. W świetle art. $3 \S 2$ ustawy z dnia 30 sierpnia 2002 r. Prawo o postępowaniu przed sądami administracyjnymi (Dz. U. z 2002 r. Nr 153, poz. 1270 z późn. zm., dalej: p.p.s.a.) kontrola działalności administracji publicznej przez sądy administracyjne obejmuje m.in. orzekanie w sprawach skarg na inne niż decyzje administracyjne i postanowienia akty lub czynności z zakresu administracji publicznej dotyczące uprawnień lub obowiązków wynikających z przepisów prawa. Stosownie do art. $134 \S 1$ p.p.s.a. sąd rozstrzyga w granicach danej sprawy, nie będąc jednak związany zarzutami i wnioskami skargi oraz powołaną w niej podstawą prawną.

Przedmiotem tak rozumianej sądowej weryfikacji legalności działania administracji publicznej jest w niniejszej sprawie zarządzenie pokontrolne wydane w związku z kontrolą przeprowadzoną przez inspektora Inspekcji Ochrony Środowiska. W świetle art. 2 ust. 1 u.i.o.ś. do zadań tej służby należy m.in. kontrola podmiotów korzystających ze środowiska w rozumieniu Prawa ochrony środowiska, w szczególności w zakresie: przestrzegania przepisów o ochronie środowiska, przestrzegania decyzji ustalających warunki korzystania ze środowiska 
oraz zakresu, częstotliwości i sposobu prowadzenia pomiarów wielkości emisji, eksploatacji instalacji i urządzeń chroniących środowisko przed zanieczyszczeniem, przestrzegania przepisów o obowiązkach przedsiębiorców w zakresie gospodarowania niektórymi odpadami oraz o opłacie produktowej i opłacie depozytowej, a także przestrzegania przepisów o zużytym sprzęcie elektrycznym i elektronicznym. Wyżej wymienione zadania kontrolne wykonuje Główny Inspektor Ochrony Środowiska, Wojewódzki Inspektor Ochrony Środowiska oraz upoważnieni przez nich inspektorzy - pracownicy Inspekcji (art. 9 ust. 1 u.i.o.ś.). Zarządzenie pokontrolne podlega zaskarżeniu do sądu administracyjnego na podstawie art. $3 \S 2$ pkt 4 p.p.s.a.

Przywołanie powyższych regulacji jest niezbędne dla wyjaśnienia istoty art. 12 ust. 1 pkt 1 u.i.o.ś., który stanowił podstawę prawną wydania zaskarżonego $\mathrm{w}$ niniejszej sprawie zarządzenia. Zgodnie z art. 12 ust. 1-3 u.i.o.ś.:

1. Na podstawie ustaleń kontroli Wojewódzki Inspektor Ochrony Środowiska może:

1) wydać zarządzenie pokontrolne do kierownika kontrolowanej jednostki organizacyjnej lub osoby fizycznej; [...]

2. Kierownik kontrolowanej jednostki organizacyjnej lub kontrolowana osoba fizyczna, w terminie wyznaczonym $\mathrm{w}$ zarządzeniu pokontrolnym, mają obowiązek poinformowania wojewódzkiego inspektora ochrony środowiska o zakresie podjętych i zrealizowanych działań służących wyeliminowaniu wskazanych naruszeń.

3. Wojewódzki inspektor ochrony środowiska może zażądać od kierownika kontrolowanej jednostki organizacyjnej przeprowadzenia postępowania służbowego lub innego przewidzianego prawem postępowania przeciwko osobom winnym dopuszczenia do uchybień i poinformowania go, w określonym terminie, o wynikach tego postępowania i o podjętych działaniach.

Nie ulega zatem wątpliwości, że $w$ przypadku złożonej struktury podmiotu, adresatem zarzqdzenia pokontrolnego może być kierownik jednostki, będacej przedmiotem kontroli. Należy jednak 4/2012 zważyć znaczenie kluczowych w badanej sprawie określeń ,jed- 
nostka organizacyjna” oraz „kierownik”. Zdaniem Sądu, jednostkę organizacyjna należy rozumieć jako wyodrębniona $w$ strukturze spótki samodzielna komórkę, oddziat. Zgodnie z odpisem Krajowego Rejestru Sądowego, Nr KRS: [...], dla [...] Sp. z o.o. w Rubryce 3 Działu 1 brak jest wpisów o oddziałach podmiotu. Należy zatem poddane kontroli miejsce traktować nie jako samodzielny oddziat, a jedynie nieruchomość należąca do spótki.

Ponadto brak, zdaniem Sądu, podstaw dla uznania A. K. właściwym adresatem dla zarządzenia pokontrolnego. Za kierownika należy uznać osobę kierująca, zarządzająca działem instytucji, przedsiębiorstwa, należacca do kierownictwa instytucji, organizacji. A. K. podczas kontroli reprezentowała spótkę na podstawie udzielonego jej petnomocnictwa $w$ zakresie odbioru zawiadomienia o zamiarze wszczęcia kontroli, odbioru upowaznienia do przeprowadzenia kontroli, zakończenia kontroli, złożenia wyjaśnień $i$ zastrzeżeń do protokołu kontroli oraz wszystkich czynności kontrolnych. Zarządzenie stanowiące przedmiot skargi do Wojewódzkiego Sq̨du Administracyjnego stanowi czynność pokontrolną. Wobec wygaśnięcia petnomocnictwa dla A. K. na etapie złożenia wyjaśnień i zastrzeżeń do protokołu, należy zgodzić się z argumentacja organu co do braku podstaw dla kierowania do niej zarządzeń pokontrolnych. Zgodnie z zapisami KRS osobq uprawniona do jednoosobowej reprezentacji [...] Sp. z o.o. jest G. N., sprawujacy funkcje prezesa zarządu. Trudno też uznać, że A. K. byłaby zdolna samodzielnie doprowadzić do wykonania obowiązków mogących wynikać z art. 12 u.i.o.ś. Skierowanie zarządzenia pokontrolnego do G. N., po pierwsze jako reprezentującego spótkę, a po drugie jako rzeczywiście władnego podjąć decyzję o realizacji działań stużacych wyeliminowaniu wskazanych naruszeń, należy uznać jako właściwe i skuteczne.

Nie można przy tym wyciągać odmiennych wniosków z treści protokołu kontroli, w którym określono A. K. jako kierownika skupu (lub też kierownika kontrolowanej jednostki). Okoliczność nieprawidłowego określenia funkcji nie może kreować faktu, że osoba ta w rzeczywistości pełniła tę funkcję, gdy z powyższych rozważań wynikają odmienne wnioski.

Odnośnie zarzutu naruszenia norm prawa materialnego polegającego na błędnej klasyfikacji działalności spółki na tere- 
nie nieruchomości należy zwrócić uwagę na brzmienie art. 28 ust. 1 ustawy o odpadach stanowiącego, że prowadzenie zbierania odpadów oraz transport odpadów wymaga uzyskania zezwolenia, z zastrzeżeniem art. 31 ust. 1, art. 32 ust. 1 oraz art. 33 ust. 1 a i 4 . Przez zbieranie odpadów zgodnie $z$ art. 3 ust. 3 pkt 23 ustawy należy rozumieć każde działanie, w szczególności umieszczanie $\mathrm{w}$ pojemnikach, segregowanie i magazynowanie odpadów, które ma na celu przygotowanie ich do transportu do miejsc odzysku lub unieszkodliwiania. Argumentacja skarżacej, że odpady, których obecność stwierdzono na terenie kontrolowanej nieruchomości, nie sq magazynowane, a jedynie oczekują na przeładunek, jest nie do przyjęcia i stanowi próbe obejścia prawa. Dla wypełnienia definicji art. 3. ust. 3 pkt 23 cyt. ustawy wystarczające jest stwierdzenie w toku kontroli obecności na terenie nieruchomości kontenera $\mathrm{z}$ odpadami, co wobec braku wymaganego pozwolenia na składowanie oraz zgody lokalizacyjnej stanowi naruszenie art. 28 ust. 1 u.o.

Należy podkreślić, że spółka mylnie odwoływała się do tego, że nie prowadziła skupu odpadów, ponieważ organ w protokole kontroli nie zarzucał spółce takiego sposobu działania. Z protokołu wynika wprost, że organ zarzucił spółce zbieranie odpadów złomu, a nie dokonywanie jego skupu. Organ w tym zakresie w prawidłowy sposób posłużył się nomenklaturą wynikającą z ustawy o odpadach (art. 3 ust. 3 pkt 23).

\section{WYROK WSA W KIELCACH Z DNIA 21 CZERWCA 2012 R., SYGN. II SA/KE 257/12}

W tej sprawie Samorządowe Kolegium Odwoławcze uchyliło decyzję Burmistrza w sprawie dotyczącej usunięcia z terenu bazy magazynowo-przeładunkowej 25 zgromadzonych odpadów komunalnych zmieszanych i niesegregowanych oraz innych gromadzonych na terenie bazy odpadów, na których zbieranie na danej nieruchomości spółka nie posiada zezwolenia.

Rozstrzygnięcie organu odwoławczego zapadło w następującym stanie faktycznym.

Wojewódzki Inspektor Ochrony Środowiska poinformował organ I instancji, że w wyniku oględzin przeprowadzonych na 
terenie bazy magazynowo-przeładunkowej należącej do spółki A., stwierdzono, że znajdują się tam 3 kontenery z odpadami komunalnymi o pojemności ok. $40 \mathrm{~m}^{3}$, przygotowane do wywiezienia. Ze względu na wydanie przez Samorządowe Kolegium Odwoławcze decyzji stwierdzającej nieważność decyzji Starosty udzielającej A. pozwolenia na prowadzenie działalności w zakresie zbierania i transportu odpadów w części dotyczącej zbierania odpadów, wniesiono o zastosowanie $\mathrm{w}$ niniejszej sprawie art. 34 ustawy z dnia 27.04.2001 r. o odpadach (Dz. U. z 2010 nr 185, poz. 1243 j.t.).

Organ I instancji stwierdził, że A. bez wymaganego zezwolenia prowadzi działalność w zakresie zbierania odpadów w tym ich składowania i magazynowania w miejscu nieprzeznaczonym do składowania i magazynowania odpadów. Z tego też względu organ I instancji, działając na podstawie art. 34 ustawy o odpadach, nakazał A. usunięcie $\mathrm{z}$ terenu bazy magazynowo - przeładunkowej zlokalizowanej 25 zgromadzonych odpadów komunalnych zmieszanych i niesegregowanych (200301), 1 kontenera wewnątrz hali i 2 kontenerów na zewnątrz, stłuczki szklanej w ilości około $20 \mathrm{~m}^{3}$, opakowań z papieru i tektury o pojemności około $60 \mathrm{~m}^{3}$.

Spółka wniosła odwołanie do SKO. Samorządowe Kolegium Odwoławcze podniosło, że określenie miejsca i sposobu magazynowania odpadów następuje $\mathrm{w}$ zezwoleniu na prowadzenie działalności $\mathrm{w}$ zakresie odzysku lub unieszkodliwienia odpadów lub zezwoleniu na prowadzenie działalności w zakresie zbierania lub transportu odpadów. Mając na uwadze treść ww. decyzji własnej z dnia [...] organ odwoławczy podniósł, że konsekwencją stwierdzenia nieważności decyzji Starosty K. z dnia [...] w części dotyczącej zbierania odpadów - wskazującej jako miejsce magazynowania odpadów nieruchomość w S. - jest to, iż organ I instancji zasadnie przyjął, iż teren nieruchomości w S. 25 nie jest miejscem przeznaczonym do zbierania odpadów a zatem zasadnie zobowiązał firmę A. do usunięcia odpadów z tej nieruchomości jako miejsca do tego nieprzeznaczonego.

Uzasadniając konieczność zmiany zaskarżonej decyzji w oparciu o art. $138 \S 1$ pkt 2 k.p.a. - Kolegium powołało się 
na wyniki ponownie przeprowadzonych oględzin, w trakcie których ustalono, że ilość i rodzajodpadów, do których usunięcia zobowiązany został A., uległa zmianie w stosunku do stanu z daty wydania zaskarżonej decyzji. Za zbędne uznano zobowiązywanie strony do zawarcia umowy na usunięcie odpadów i ich transport do miejsca składowania lub unieszkodliwienia z przedsiębiorcą posiadającym zezwolenie jako, że A. może to uczynić we własnym zakresie, gdyż ww. zezwolenie Starosty K. w części dotyczącej transportu odpadów jest nadal ważne.

W skardze do Wojewódzkiego Sądu Administracyjnego spółka A. zarzuciła decyzji organu odwoławczego naruszenie: 1. art. $97 \S 1$ pkt 4 k.p.a., poprzez uznanie, że Kolegium prawomocnie rozstrzygnęło $\mathrm{w}$ przedmiocie stwierdzenia nieważności czesści decyzji Starosty K. z dnia [...] i nie zawieszenie postępowania $\mathrm{w}$ niniejszej sprawie; 2 . art. $138 \S 2$ k.p.a. poprzez nie przekazanie sprawy organowi I Instancji do ponownego rozpoznania, z uwagi na fakt, że rozstrzygnięcie sprawy wymaga uprzednio przeprowadzenia postępowania wyjaśniającego, przynajmniej w znacznej części, a przede wszystkim prawomocnego rozstrzygnięcia $\mathrm{w}$ przedmiocie stwierdzenia nieważności części ww. decyzji z dnia [...], 3. art. 107 § 3 k.p.a. poprzez pominięcie $\mathrm{w}$ zaskarżonej decyzji uzasadnienia faktycznego i prawnego, w szczególności poprzez ograniczenie się jedynie do przedstawienia i umotywowania własnego stanowiska Kolegium.

(...)W odpowiedzi na skargę organ odwoławczy wniósł o jej oddalenie, podtrzymując argumentację przedstawioną w uzasadnieniu zaskarżonego rozstrzygnięcia.

Wojewódzki Sąd Administracyjny stwierdził, że skarga nie zasługiwała na uwzględnienie. Rozpatrując skargę w ramach tak zakreślonej kognicji Wojewódzki Sąd Administracyjny nie dopatrzył się naruszeń prawa skutkujących koniecznością uchylenia bądź stwierdzenia nieważności decyzji organu odwoławczego. Materialnoprawną podstawę wydania zaskarżonej decyzji stanowił art. 34 ustawy z dnia 27.04.2001 r. o odpadach (Dz. U. z 2010 nr 185, poz. 1243 j.t.), zwanej dalej ustawa, zgodnie z którym wójt, burmistrz lub prezydent miasta, $w$ drodze decyzji, naka4/2012 zuje posiadaczowi odpadów usunięcie odpadów z miejsc nieprze- 
znaczonych do ich składowania lub magazynowania, wskazujacc sposób wykonania tej decyzji. Decyzja, o której stanowi powołany przepis, jest wydawana z urzędu i ma obligatoryjny charakter. $W$ kazdym bowiem przypadku stwierdzenia przez właściwy organ składowania lub magazynowania odpadów przez ich posiadacza $w$ miejscu, które nie stanowi składowiska odpadów lub nie zostato określone $w$ sposób wyraźny jako miejsce magazynowania odpadów $w$ stosownej decyzji, informacji lub zgłoszeniu, o których stanowi art. 63 ust. 6 ustawy, organ ten, działając na podstawie art. 34 ust. 1 ustawy, jest zobowiązany nakazać ich usunięcie z tego miejsca jako z miejsca nieprzeznaczonego do ich składowania lub magazynowania (por. wyrok NSA z dnia 20.07.2011r., sygn. akt II OSK 1162/10,LEX nr 1083560).

Zgodnie z art. 28 ust. 1 tej ustawy prowadzenie zbierania odpadów oraz transport odpadów wymaga uzyskania zezwolenia, z zastrzeżeniem art. 31 ust. 1 , art. 32 ust. 1 oraz art. 33 ust. 1 a i 4 . Jak wynika z kolei z art. 28 ust. 5 pkt 3 $w$ zezwoleniu na zbierania lub transport odpadów określa się w przypadku zbierania odpadów miejsce $i$ sposób oraz rodzaj magazynowanych odpadów, a takize opis sposobu dalszego zagospodarowania odpadów. Z kolei pojęcie zbierania odpadów zdefiniowane zostało w art. 3 ust. 3 pkt 23 ustawy o odpadach jako każde działanie, w szczególności umieszczanie w pojemnikach, segregowanie i magazynowanie odpadów, które ma na celu przygotowanie ich do transportu do miejsc odzysku lub unieszkodliwienia. Natomiast w myśl art. 3 ust. 3 pkt 3 przez magazynowanie odpadów należy rozumieć czasowe przetrzymywanie lub gromadzenie odpadów przed ich transportem, odzyskiem lub unieszkodliwianiem.

Jak prawidłowo ustaliły organy obu instancji decyzją z dnia [...] Samorządowe Kolegium Odwoławcze stwierdziło nieważność decyzji Starosty K. z dnia [...], udzielającej A. zezwolenia na prowadzenie działalności w zakresie zbierania i transportu odpadów w części dotyczącej zbierania odpadów a więc zgodnie $\mathrm{z}$ powołanymi przepisami również $\mathrm{w}$ zakresie ich przetrzymywania lub gromadzenia przed transportem, odzyskiem lub unieszkodliwianiem. Decyzją z dnia 23.12.2010r. Kolegium, po rozpatrzeniu wniosku A. o ponowne rozpatrzenie 
sprawy, utrzymało w mocy decyzję własną z dnia [...] Nie jest kwestionowane, że rozstrzygnięcie to nie zostało zaskarżone do Wojewódzkiego Sądu Administracyjnego. W świetle powyższego należy stwierdzić, że ww. rozstrzygnięcie Kolegium jest ostateczne i prawomocne, a pomimo wszczynanych na wniosek A. kolejnych postępowań (w trybie art. 145 i 156 k.p.a.) dotyczących tych decyzji nie zostały one skutecznie usunięte $\mathrm{z}$ obrotu prawnego.

W tym zakresie należy wyjaśnić stronie skarżącej, że zgodnie z art. 269 k.p.a. decyzje określone w innych przepisach prawnych jako prawomocne uważa się za ostateczne, chyba że z przepisów tych wynika, iż dotyczą one takiej decyzji, która została utrzymana w mocy w postępowaniu sądowym bądź też nie została zaskarżona $\mathrm{w}$ tym postępowaniu $\mathrm{z}$ powodu upływu terminu do wniesienia skargi. Z kolei, jak wynika z ustanowionej w art. $16 \S 1$ k.p.a. zasady ogólnej trwałości decyzji ostatecznych przymiot ostateczności przysługuje decyzjom, od których nie służy odwołanie w administracyjnym toku instancji lub wniosek o ponowne rozpatrzenie sprawy. Formalna strona tej zasady wyraża się w tym, że decyzja ostateczna obowiązuje dopóty, dopóki nie nastąpi uchylenie lub zmiana takiej decyzji, bądź stwierdzenie jej nieważności. Jest to więc tzw. domniemanie mocy obowiązującej ostatecznej decyzji administracyjnej, a podważenie trwałości tego rozstrzygnięcia jest możliwe wyłącznie w trybach nadzwyczajnych.

Mając na uwadze powyższe należy stwierdzić, że ww. decyzja Kolegium jest ostateczna oraz prawomocna. Okoliczności tej nie zmienia wznowienie - na wniosek A. - postępowania w sprawie zakończonej ww. decyzją z dnia [...] - postanowieniem Samorządowego Kolegium Odwoławczego z dnia 20.07.2011r. jako, że decyzją z dnia 25.08.2011r., wydaną na podstawie art. $151 \S 1$ pkt $1 \mathrm{w}$ zw. z art. $145 \S 1$ pkt 3 k.p.a., organ ten odmówił uchylenia decyzji z dnia [...] Decyzja z dnia 25.08.2011r. została utrzymana w mocy decyzją Kolegium z dnia 30.01.2012r., a wyrokiem z dnia 13.06.2012r. w sprawie sygn. akt II SA/Ke 263/12 Wojewódzki Sąd Administracyjny oddalił skargę A. na ostatnią z ww. decyzji. 
Ze względu na powyższe za niezasadny należy uznać zarzut skargi o naruszeniu przez organ art. $97 \S 1$ pkt 4 k.p.a. zwłaszcza, że - jak wynika z akt administracyjnych - strona nie składała $\mathrm{w}$ toku prowadzonego postępowania wniosku o jego zawieszenia. Podejmowane zaś przez A. bezowocne próby wzruszenia $w$ trybach nadzwyczajnych decyzji z dnia [...] nie mogą usprawiedliwiać przedłużania postępowania w sprawie usunięcia odpadów, na jakich zbieranie spółka ta - stosownie do tego ostatecznego rozstrzygnięcia - nie ma już zezwolenia.

Dla rozstrzygnięcia niniejszej sprawy nie ma także znaczenia wskazywana w uzasadnieniu skargi okoliczność wydania przez Głównego Inspektora Nadzoru Ochrony Środowiska postanowienia $\mathrm{z}$ dnia [...] o zawieszeniu postępowania w sprawie nałożenia na A. kary w wysokości 100.000 zł za prowadzenie działalności w zakresie zbierania odpadów bez ważnego zezwolenia. Postępowanie to dotyczy bowiem innej sprawy niż będąca przedmiotem niniejszego rozpoznania.

Konsekwencją stwierdzenia nieważności decyzji Starosty K. $z$ dnia [...] w części dotyczącej udzielenia zezwolenia na zbieranie odpadów byty prawidłowe ustalenia organów obu instancji, że teren nieruchomości $w$ S. 25 nie jest miejscem przeznaczonym do zbierania (magazynowania) odpadów.

Odnośnie zakresu przedmiotowego zaskarżonej decyzji wskazać trzeba, że Kolegium orzekając w tym przedmiocie prawidłowo oparło się na ustaleniach poczynionych w trakcie postępowania odwoławczego przez organ I instancji, działający w trybie art. 136 k.p.a. Niewątpliwie przeprowadzenie w tym trybie $\mathrm{w}$ dniu [...] ponownych oględzin $\mathrm{w}$ bazie magazynowo-przeładunkowej zlokalizowanej w S. 25 było uzasadnione, jeśli się zważy, że obowiązkiem organu odwoławczego jest orzekanie na podstawie stanu faktycznego istniejącego w dacie wydania decyzji. Przedmiotowe oględziny potwierdziły, co do zasady, zgromadzenie w bazie skarżącej znacznych ilości odpadów, wykazując jednakże zmiany w zakresie ich ilości oraz rodzaju. Tak więc, organ odwoławczy zasadnie wydał rozstrzygnięcie na podstawie art. $138 \S 1$ pkt 2 k.p.a.

Wbrew zarzutom skargi, brak było w niniejszej sprawie podstaw do zastosowania art. $138 \S 2$ k.p.a. Wydanie w tym try- 
bie decyzji kasacyjnej i przekazanie sprawy organowi I instancji do ponownego rozpatrzenia jest możliwe wyłącznie wtedy, gdy decyzja organu I instancji została wydana z naruszeniem przepisów postępowania, a konieczny do wyjaśnienia zakres sprawy ma istotny wpływ na jej rozstrzygnięcie.

W stanie faktycznym rozpoznawanej sprawy, w ocenie Sądu, nie zachodziły przesłanki do wydania decyzji kasacyjnej. Ponowne oględziny potwierdziły dokonane $\mathrm{w}$ toku postępowania I - instancyjnego ustalenia dotyczące składowania i magazynowania odpadów w miejscu do tego nieprzeznaczonym, różniąc się jedynie co do ilości oraz rodzaju tych odpadów.

Zdaniem Sądu - wbrew zarzutom skargi - uzasadnienie zaskarżonej decyzji spełnia wymogi z art. 107 § 3 k.p.a. Organ przedstawił bowiem stan faktyczny sprawy oraz argumentację prawną wydanego rozstrzygnięcia.

Końcowo podkreślenia wymaga, że zezwolenie na transport odpadów (którym nadal dysponuje A.) nie jest równoznaczne z zezwoleniem na ich zbieranie czy też magazynowanie. Dla rozstrzygnięcia niniejszej sprawy nie miały też znaczenia wyjaśnienia J. M. złożone do protokołu oględzin w dniu [...], że część odpadów była już przygotowana do przeładowania do kontenerów i wywiezienia, gdyż zgodnie z art. 3 ust. 3 pkt 23 ustawy zbieranie odpadów odnosi się do każdego działania, które ma na celu przygotowanie ich do transportu do miejsc odzysku lub unieszkodliwienia.

Skoro zatem podniesione w skardze zarzuty nie mogły odnieść zamierzonego skutku, a jednocześnie brak jest okoliczności, które z urzędu należałoby wziąć pod uwagę, Wojewódzki Sąd Administracyjny orzekł jak w sentencji wyroku na podstawie art. 151 ustawy p.p.s.a. 